\title{
MODELING THE ORGANISATIONAL IMPLEMENTATION OF A DRONE AND COUNTER-DRONE OPERATOR INTO THE SERBIAN ARMED FORCES RIFLE SECTION
}

\author{
Vinko Žnidaršič ${ }^{*}$ \\ Marko Radovanović** \\ Dragan Stevanović ${ }^{* * *}$
}

\begin{tabular}{ll}
\hline Достављен: 13. 04. 2020 & Језик рада: Српски \\
Прихваћен: 12.11 .2020 & Tип рада: Прегледни рад \\
& DOI број: $10.5937 /$ vojdelo2003084Z
\end{tabular}

rones are one of the new threats to tactical units. The armed forces use them with various successes in operations. However, the smallest tactical unit such as rifle section is generally still unprepared to operate drones and perform counter measures. Drones have a wide range of capabilities and therefore can be used for both civilian and military purposes. Along with the development of drones, counter-drone systems have also been developed.

Several small drones and counter-drone systems suitable for the use by one man are presented in the first part of the research results to show that there is more than one system that can be selected for operational use. This also shows that one soldier in rifle section is capable of operating a small drone and counter-drone systems.

This research has aimed to survey the organizational structure and determine organizational capabilities to implement a drone and counter-drone operator duty in rifle section. For that purpose, the research team has conducted a series of interviews with officers and non-commissioned officers of the Serbian Armed Forces and the Ministry of Defense. This duty is defined as „a drone operator" and in this research the Serbian

\footnotetext{
*Vinko Žnidaršič, the University of Defence in Belgrade, the Military Academy, ORCID iD: 0000-0002-1449-0448, e-mail: vinko.znidarsic@gmail.com. This research paper has been conducted as a part of the project funded by the Military Academy of the University of Defence in Belgrade, number: VA-DH/2/18-20, „Podrška procesu donošenja vojnih odluka”.

** Marko Radovanović, the Serbian Armed Forces, $1^{\text {st }}$ Army Brigade, ORCID iD: 0000-0002-9866-9639, e-mail: markoradovanovicgdb@yahoo.com.

*** Dragan Stevanović, the University of Defence in Belgrade, Rectorate.
} 
Armed Forces rifle section is modeled in such a way to include a duty for 1) a specialized rifleman, 2) a converted sniper, or 3) an embedded soldier.

Key words: rifle section (rifle squad), drone, counter - drone, drone operator, command, small tactical units

\section{Introduction}

T he threat of drones is no longer a possibility. It is the reality that has to be accepted. Several drone attacks launched in Marawi (23 May - 23 October 2017), Caracas (4 August 2018), Anad Base (10 January 2019), Hmeimim Air Base (11 January 2018), Abqaiq and Khurais facilities (14 September 2019), as well as in many other places, indicate that drones are being increasingly used worldwide at the tactical level. ${ }^{1,2,3,4,5}$ Over time drones have become technically capable of performing more and more functions and cheaper for production, smaller and deadlier. Having in mind all these facts, it can be concluded that it is a matter of time before drones will start to be more widely used in units like infantry company, platoon and section, and the mentioned units should be prepared to use drones and successfully perform counter-drone activities.

The impact that drones will have on the future conduct of warfare will primarily depend on technological innovations in the field of robotics, telecommunications, weapons and optoelectronic devices. In the future, drones will continue to serve as an integral part of the human-controlled system. ${ }^{6}$ The possibility of using small drones and counter-drone equipment at the lowest tactical level is justified and should not be mixed with the use of medium and large drones with a far larger range and possibilities of their use. The analysis of the mentioned events, especially those in Marawi in 2017, showed that small infantry units had not been ready to oppose

\footnotetext{
${ }^{1}$ Lewis James, „Contemporary Operating Environment - The Battle Of Marawi: Small Team Lessons Learned For The Close Fight", The Cove, 26 November 2018, https://cove.army.gov.au/article/the-battle-marawi-small-team-lessons-learned-the-close-fight, 30/01/2020.

2 Barry Jenkins, „We should fear the use of killer drones like in Venezuela”, The Independent, 11 August 2018, https://www.independent.co.uk/voices/killer-drones-venezuela-president-attack-uk-aircraftwarfare-isis-syria-a8487536.html,15/11/2019.

${ }^{3}$ Mahmood Ali, Aldroubi Mina, „Houthi rebel drone targets senior officers at Yemen's Al Anad military base", The National, 10January 2019, https://www.thenational.ae/world/mena/houthi-rebeldrone-targets-senior-officers-at-yemen-s-al-anad-military-base-1.811544, 03/08/2019.

${ }^{4}$ Reid David, „A swarm of armed drones attacked a Russian military base in Syria”, SNBC, 11 January 2018, https://www.cnbc.com/2018/01/11/swarm-of-armed-diy-drones-attacks-russian-military-basein-syria.html, 30/01/2020.

${ }^{5}$ Reid David, „Saudi Aramco reveals attack damage at oil production plants”, SNBC, 21 September 2019, https://www.cnbc.com/2019/09/20/oil-drone-attack-damage-revealed-at-saudi-aramco-facility.html, 14/02/2020.

${ }^{6}$ Jović Željko, „Strategijski i legalni aspekti borbene upotrebe dronova u protivterorističkim operacijama SAD", Vojno delo, Volume 69, Issue 7 (2017): DOI: 10.5937/vojdelo1707468J, page 479.
} 
the drones used by the equal tactical units and that they eventually had started to use small drones to counter the threat. ${ }^{7}$

Drones are in use by large military forces for gathering pieces of information by observing and recording from the air, water and ground. The use of small drones gives section commanders the opportunity to have a clearer picture of what is going around section, without putting soldiers at risk of injuries or death.

The research has assumed that it is not a problem to introduce drone and counter-drone equipment into infantry section. The problem that this research has addressed is the personnel who would manage the equipment. The theoretical solution for this problem is designed in such a way that one man and drones are considered to be Unmanned Aerial Vehicle (UAV) and Unmanned Ground Vehicle (UGV). The focus of the research is on the possibility of introducing duties into the existing organization and thus covering only the theoretical aspect of problemsolving because at the time of the research these duties have not been in the organizational structure of the Serbian Armed Forces.

A particular drone system has not been considered, but the general capabilities of the small UAV and UGV systems guided by one soldier. This soldier, infantryman, could and should operate a drone and be capable of countering the enemy's drone. The research objective has been to make the organization of infantry section capable of improving its operational capabilities and at the same time resist this threat by the enemy.

Only two options with several variants come as the solution. The first variant is to implement a drone operator as plus one man in rifle section. The second variant is to assign drone responsibilities to one soldier who is already in rifle section.

In addition to the benefits of drone deployment in rifle sections, there are limitations and problems that arise during the use of drones in operations: flight autonomy, limited maneuverability on afforested land, as well as in the urban environment, the ability to obstruct and bring down.

In order to improve rifle section drone and counter-drone capability the research has been conducted with the premise that this requirement could be done by implementing a new duty with rifle section, but not necessarily and an extra man for that. This duty is marked as "a drone and counter-drone operator", or simply as "a drone operator". These two functions are gathered into one duty considering the fact and opportunity that small drone technology and counter-drone systems could be manufactured to be small and allow that one man could operate them. The best man for counter-drone systems is the one who knows how to operate them.

The analysis of the "Regulation of rifle soldier-section" as an initial document has revealed that the organizational structure of rifle section is composed of nine members: the rifle section commander (KO, "komandir odeljenja"), machine gunner-1 (H-1, "prvi nišandžjja"),

\footnotetext{
${ }^{7}$ Lewis James, „Contemporary Operating Environment - The Battle Of Marawi: Small Team Lessons Learned For The Close Fight", The Cove, 26 November 2018,

https://cove.army.gov.au/article/the-battle-marawi-small-team-lessons-learned-the-close-fight, 30/01/2020.
} 
assistant machine gunner-1 (Пo-1, "pomoćnik nišandžije-1"), machine gunner-2 (H-2, "drugi nišandžija"), assistant machine gunner-2 (Пo-2, "pomoćnik nišandžije-2"), rifleman-1 (C-1, "prvi strelac"), rifleman-2 (C-2, "drugi strelac"), rifleman-3 (C-3, "treći strelac") and sniper ( $\mathrm{CH}_{\mathrm{H}}$ "snajperista"). The rifle section personnel is armed with four automatic rifles, two machine guns and one semi-automatic sniper rifle (Figure 1). ${ }^{8}$

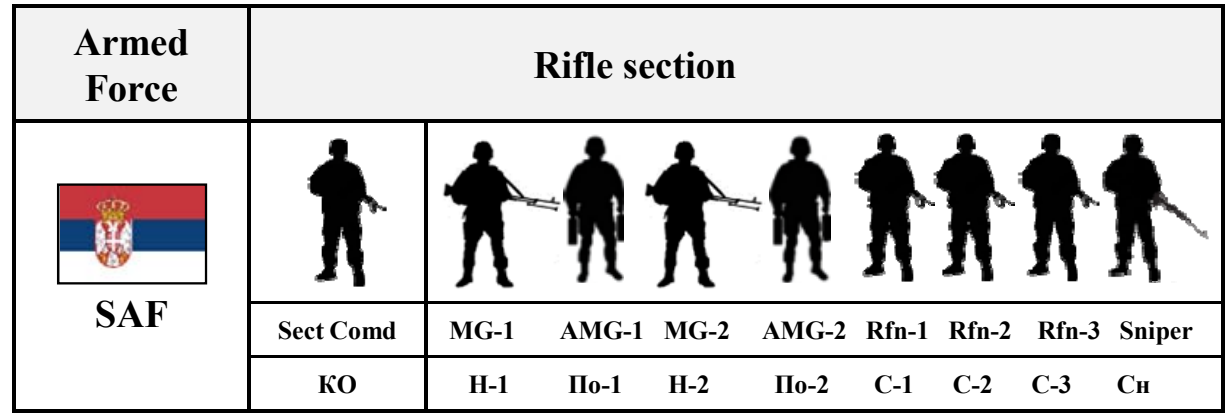

Figure 1 - Rifle section organizational structure

Usually, the rifle section commander is directly superior to all eight soldiers, and at the same time subordinate to a rifle platoon commander. Every soldier in rifle section has a single weapon system and assigned duties. In combat rifle section commander usually divides rifle section into two or three fire-groups with three or four solders.

In connection with solving the research problems the research team conducted a series of interviews with officers and non-commissioned officers of the Serbian Armed Forces and the Ministry of Defense during 2019 and 2020 with the aim to survey the organizational structure and determine organizational capabilities to implement a drone and counter-drone operator duty in rifle section as a subproject of the project funded by the Military Academy of the University of Defence in Belgrade, number: VA-DH/2/18-20, „Podrška procesu donošenja vojnih odluka”. The research results are presented in this paper in the form of variants of organizational structures of rifle section.

The attention is directed to the drone and counter-drone systems that can be operated only by an infantryman. In this survey rifle section is isolated, considering that other units have no influence.

\section{Drons and Counter-drone Devices for a Drone Operator}

The implementation of a new operator duty into rifle section cannot be considered without having the data about possible small drone and counter-drone systems used by one man. The objective of this part of the research has been surveying literature resources and the research team has recognized several systems that fit one soldier to handle.

8 „Pravilo vojnik-odeljenje pešadije”, KzO GŠ vS, Vojna štamparija, Belgrade, 2016, points $16-19$ and Figure 1. 
The possibility of using drones in rifle section operations is as follows: reconnaissance, detection of nuclear, chemical and biological weapon; mines detection; electronic reconnaissance; laser marking the target; jamming of the radar; carrying combat load, etc. ${ }^{9}$

Table 1 - Drones

\begin{tabular}{|l|c|c|c|c|}
\hline Equipment & Picture & Weight & Distance & User army \\
\hline $\begin{array}{l}\text { Desert Hawk } \\
\text { III }\end{array}$ & & & & \\
\hline Bayraktar Mini \\
UAV
\end{tabular}

${ }^{9}$ Aleksandar Milić, Aca Ranđelović, Marko Radovanović, „Use of drones in operations in the urban environment", $5^{\text {th }}$ International Scientific conference Safety and crisis management - Theory and practise Safety for the future - SecMan Regional Association for Security and Crisis Management S4 GLOSEC Global security doo.., Belgrade, 2019, pp. 124-130.

10 „Lockheed Martin”, https://www.flickr.com/photos/lockheedmartin/5084393936/lightbox/, 23/09/2020.

${ }^{11}$ „Bayraktar Mini Unmanned Aerial Vehicle”, https://www.army-technology.com/projects/bayraktaruav/bayraktar-uav1, 23/09/2020.

12 „EMT Aladin”, https://alchetron.com/EMT-Aladin\#emt-aladin-62593bd3-198f-471d-a78bdc741a5ff47-resize-750.jpeg, 23/09/2020. 


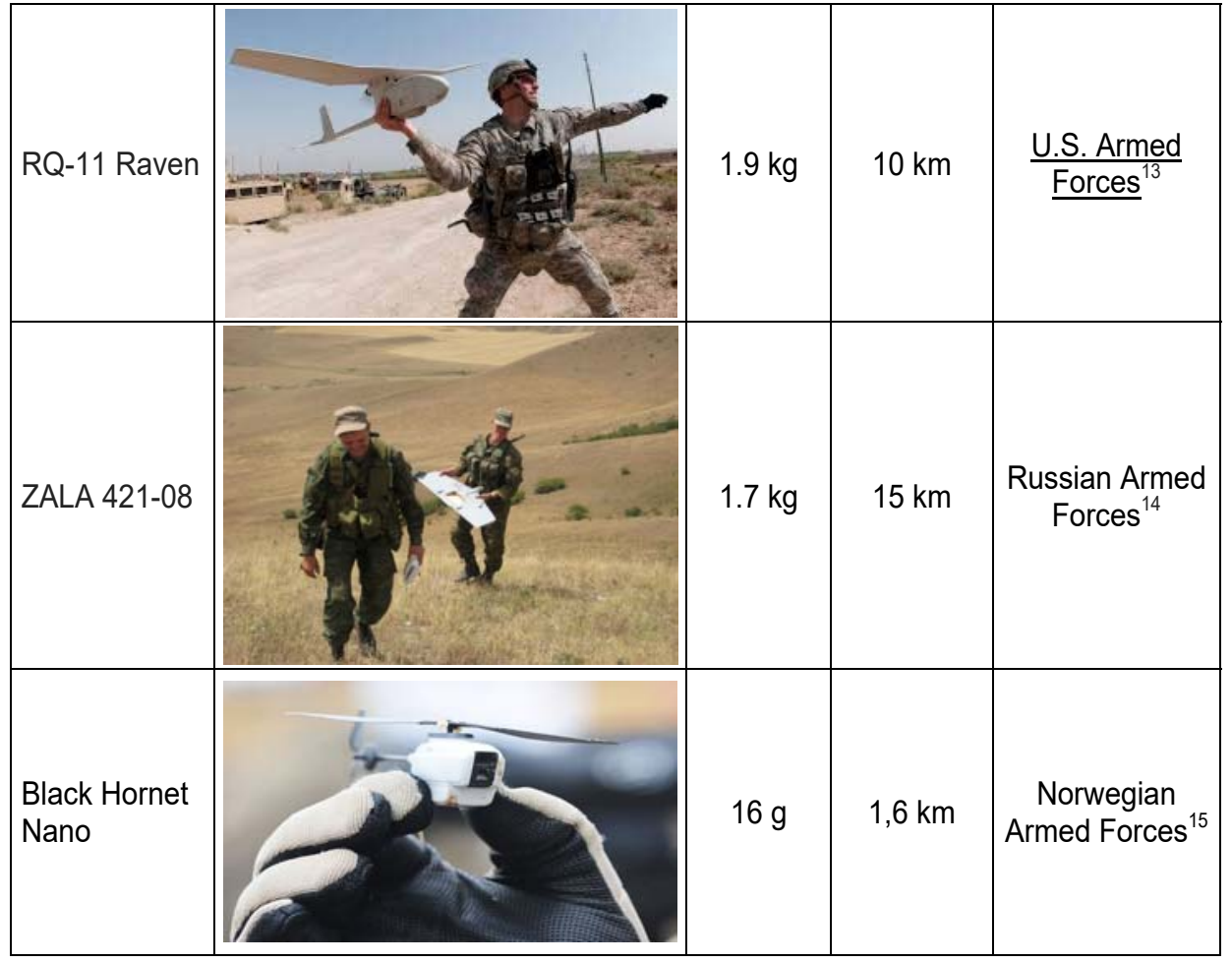

During the analysis of drones in order to be put into use in rifle section, there are limitations, and the most important ones are the size and type of drone. The paper discusses small drones used for military and commercial purposes, operated by a single operator. One man in rifle section could use a small drone with rotating and fixed aeroprophilic surfaces, with energy from battery cells, where lithium-ion (Li-lon) has proved to be the most effective battery, with up to $15 \mathrm{~km}$ long flight range, flight autonomy of up to 2 hours and the possibility of carrying additional loads up to $1.5 \mathrm{~kg}$.

A rifle section drone operator may be able to remotely observe, detect people and various objects ${ }^{16}$ as mines (on and under surface), conduct electronic and

${ }^{13}$ „RQ-11 Raven US Army Unmanned Aerial Vehicle”, http://usaircraftpics.blogspot.com/2012/03/rq-11-raven-us-army-unmanned-aerial.html, 23/09/2020.

14 „Russian UAVs Part 1”, http://igorrgroup.blogspot.com/2010/05/russia-uavs-part-1.html, 23/09/2020.

15 "Black Hornet Nano",

https://upload.wikimedia.org/wikipedia/commons/thumb/e/ed/Black_Hornet_Nano_Helicopter_UAV. jpg/800px-Black_Hornet_Nano_Helicopter_UAV.jpg, 23/09/2020.

${ }^{16}$ Eleftheria Mitka, Spiridon G. Mouroutsos, „Classification of Drones”, American Journal of Engineering Research, Vol 6, 7/2017, pp. 36-41. 
counter electronic warfare. ${ }^{17}$ Drones in rifle section could also serve for larger units as a communication relay, hyper spectral scanning, radar imaging, laser tagging, interfering with radars, carrying combat load, target shooting, deployment and implementation into artillery and even as mortar fire control system.

When considering the introduction of drone and counter-drone operators in infantry rifle sections, the attention should also be paid to the introduction of landless platform operators (Table 2), which would significantly increase the efficiency of rifle sections and adapt tactics to contemporary security challenges, risks and threats. The use of these platforms improves the following elements: efficiency, effectiveness, economy, security and safety of rifle section. It creates mine detection and destruction capabilities, the ability to retrieve the wounded, the transport capability and it increases firepower.

Table 2 - Multi-Utility Tactical Transport and Unmanned Ground Vehicle

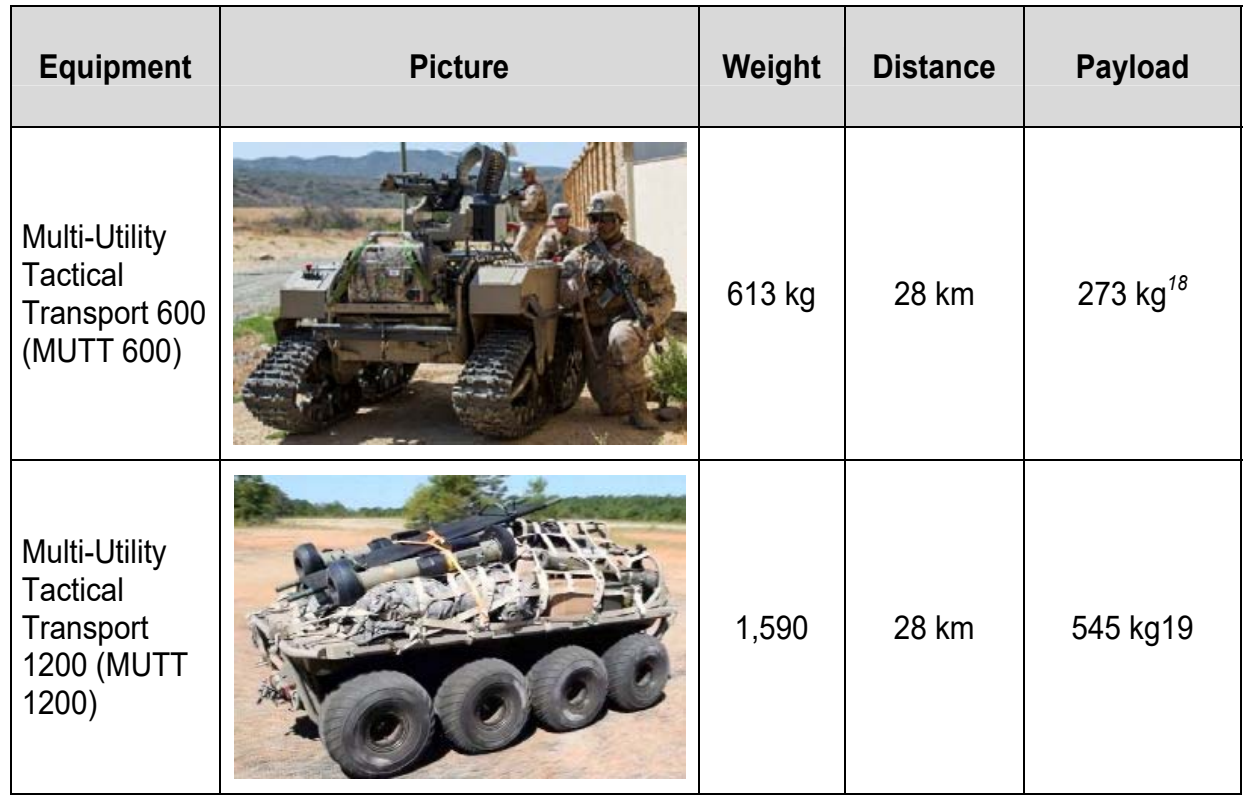

${ }^{17}$ Dragan Stevanović, Olga Isaijeva, Dejan Ranđelović, Miroslav Terzić, „Upotreba dronova u vojne svrhe", 14. Međunarodno savetovanje Rizik i bezbednosni inženjering - zbornik radova, Visoka tehnička škola strukovnih studija, Novi Sad, 2019, pp. 132-144.

18 John Grady, „Panel: Services Should Better Leverage Each Other's Tech Development”, Joint Operations, USNI News, 17 March 2017, https://news.usni.org/2017/03/17/panel-servicesbetter-leverage-others-tech-development-joint-operations, 01/02/2020.

${ }^{19} \mathrm{lbid}$. 


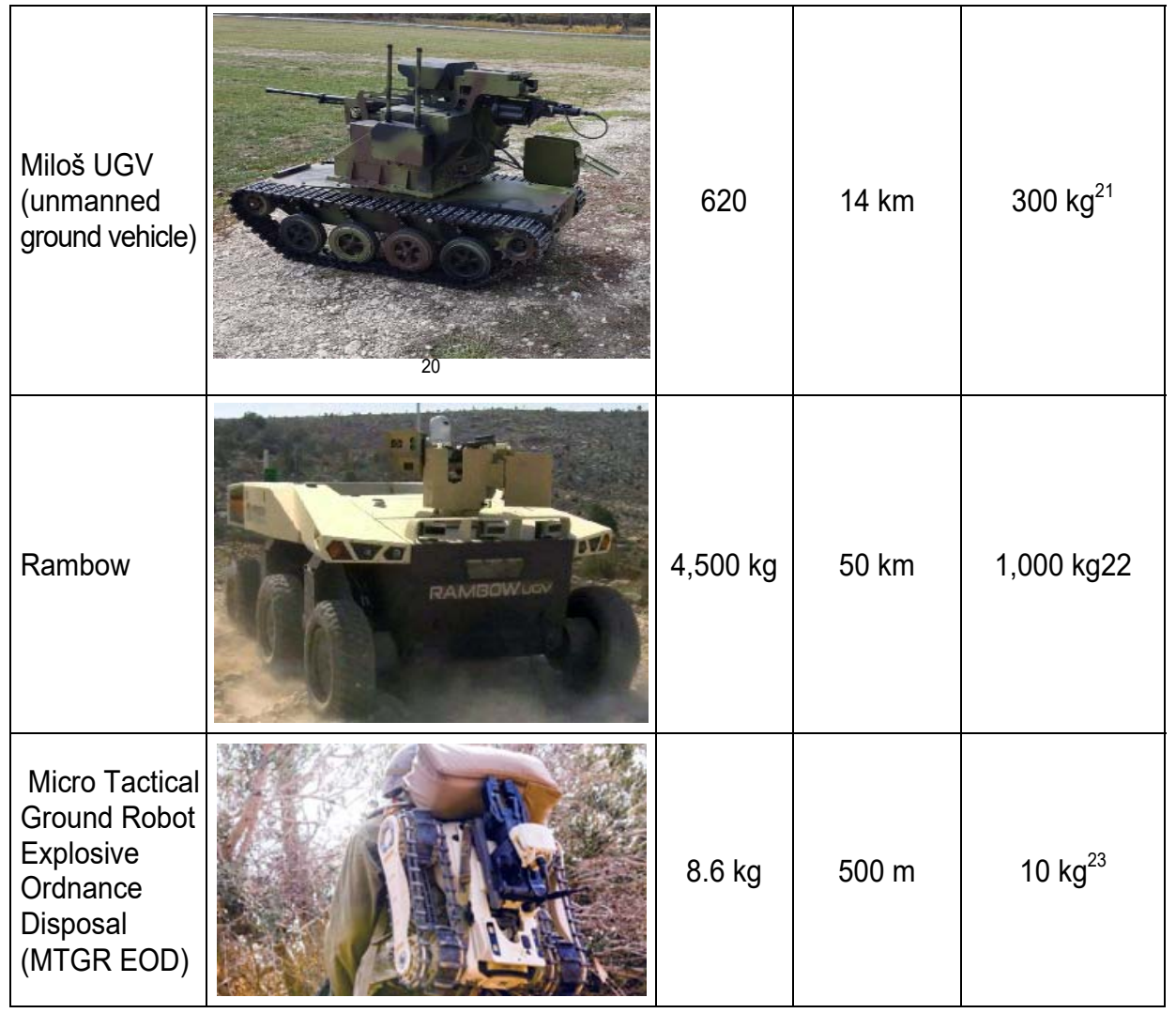

When it comes to counter-drone operator equipment, there is a possibility of using several counter-drone devices like 1) counter-drone rifles; 2) the radar system for detection and identification of drones; 3 ) drone detector; 4) drone tracker; 5) drone operator locating system; and 6) drone jammer. ${ }^{24}$

${ }^{20}$ „Daljinski upravljana besposadna zemaljska platforma Miloš”, PPT Namenska, http://www.ppt-namenska.rs/milos.html, 10/02/2020.

${ }^{21}$ Christopher F Foss, „Serbia advances Milos UGV development”, Jane's, 5 July 2019, https://www.janes.com/article/89709/serbia-advances-milos-ugv-development, 01/02/2020.

${ }_{22}^{22}$,Rambow”, Army Guide, http://www.army-guide.com/eng/product.php?prodlD=5923\&printmode=1, 05/02/2020

${ }^{23}$ "MTGR is a Lightweight Combat Proven Tactical Robot”, Roboteam, http://robo-team.com/products/mtgr/\#s-6, 05/02/2020.

${ }^{24}$ Xiufang Shi, Chaoqun Yang, Weige Xie, Chao Liang, Zhiguo Shi, Jiming Chen, „Anti-Drone System with Multiple Surveillance Technologies: Architecture, Implementation, and Challenges", IEEE Communications Magazine, Vol. 56, 4/2018, pp. 68-74. 
Counter-drone rifles are only one of several models of counter-drone activity, but they are the most convenient one when it comes to the issue of mobility and ergonomics. One operator could carry equipment with a device, which makes the drone force land or expel by jamming the signal of drone remote and navigation. ${ }^{25}$ The development of drones has also led to the development of counter-drone devices including counter-drone rifles. They enable an operator to operate drones usually up to the distances of $2 \mathrm{~km}$. Table 3 shows some models of counter-drone rifles.

This means the work by interrupting the GPS / BeiDou signal for positioning, controlling and graphically displaying drone, forcing it to automatically land or return to the position from which it took off.

Table 3 - Counter-drone rifles

\begin{tabular}{|c|c|c|c|c|}
\hline Equipment & Picture & Weight & Distance & Endurance \\
\hline REX -2 & & $3 \mathrm{~kg}$ & $500 \mathrm{~m}$ & $3 h^{26}$ \\
\hline Pishchal-PRO & & $3.5 \mathrm{~kg}^{27}$ & $2 \mathrm{~km}$ & $3 h^{28}$ \\
\hline
\end{tabular}

${ }^{25}$ Arthur Holland Michel, Counter - drone system $2^{\text {nd }}$ edition, Center for the Study of the Drone at Bard College, New York, 2019, pp. 5-12.

${ }^{26}$ „Kalashnikov creates new anti-drone gun”, Army Recognition, 10 July 2019, https://www.armyrecognition.com/weapons_defence_industry_military_technology_uk/kalashnikov _creates_new_anti-drone_gun.html, 01/02/2020.

${ }^{27}$ Nikolai Novichkov, Dmitry Fediushko, „Russia enters C-UAV domain”, European Defence Review, 26 November 2019, https://www.edrmagazine.eu/russia-enters-c-uav-domain, 01/02/2020.

${ }^{28}$ Roni Sontani, „Pishchal-PRO, Senapan Elektrik untuk Melumpuhkan Drone Berukuran Mini”, Airspace Review, 4 December 2019, https://www.airspace-review.com/2019/12/04/pishchal-prosenapan-elektrik-untuk-melumpuhkan-drone-berukuran-mini/, 17/02/2020. 


\begin{tabular}{|l|l|l|l|l|}
\hline $\begin{array}{l}\text { Almaz-Antey "flying } \\
\text { Kalashnikov rifle" }\end{array}$ & $23 \mathrm{~kg}$ & $64 \mathrm{~km}$ & $40 \mathrm{~min}^{29}$ \\
\hline Drone Gun Tactical & & & & \\
\hline
\end{tabular}

Radar is a useful tool for detecting and tracking aircraft. Radar has the challenge of detecting and tracking drones because drones have a low radar cross-section and they usually fly at low speed at a low altitude. Also, radar surveillance could detect and track drones, but it hardly exceeds 3000 meters. Radar is an active sensor that operates all day and night with high electromagnetic energy. Thus, it might be inappropriate or even forbidden to deploy high-power radars in crowded urban areas. ${ }^{33}$

${ }^{29}$ „Russians Have Made a Flying Rifle”, English Russia, 28 March 2019, https://englishrussia.com/2019/03/28/russians-have-made-a-flying-rifle/, 01/02/2020.

${ }^{30}$ „Detect. Assess. Respond.”, Drone Shield, https://www.droneshield.com/, 01/02/2020.

${ }^{31} \mathrm{lbid}$.

32 „Anti-Drone System”, Hanvy, https://www.antidrone.cn/anti-drone-system/hand-held-antidrone-gun.html, 01/02/2020.

${ }^{33}$ Anjali Nawalagatti and Arun S. Tigadi, „Anti-Drone System with Multiple Surveillance Technologies", International Journal of Engineering Science Invention, Vol. 8, May 2019, pp. 36-41. 
Radar Drone Detection System is a system with advanced phased array sweeps and target detecting technology, full time and space working mode in horizontal and it can set up 3D scan, detect, locate, and track.

Table 4 shows some models of radars for detecting and interfering with drones that can be operated by a single operator.

Table 4 - Drone detection radar

\begin{tabular}{|l|c|c|c|}
\hline \multicolumn{1}{|c|}{ Equipment } & Picture & Weight & Distance \\
\hline $\begin{array}{l}\text { Radar Drone } \\
\text { Detection }\end{array}$ & $35 \mathrm{~kg}$ & $3-5 \mathrm{~km}^{34}$ \\
\hline $\begin{array}{l}\text { QR 12- Drone } \\
\text { Detection and } \\
\text { Jamming system }\end{array}$ & & & \\
\hline $\begin{array}{l}\text { Ainstein UAV PRO } \\
\text { Radar Altimeter } \\
\text { SRD- D1 }\end{array}$ & & & \\
\hline
\end{tabular}

${ }^{34}$ „Radar Drone Detection Introduction”, Hanvy, https://www.antidrone.cn/anti-drone-system/radar-drone-detection.html, 17/02/2020.

35 „QR-12 Drone Detection And Jamming System”, Digital Eagle, https://www.digitaleagleuav.com/QR-12-Drone-Detection-And-Jamming-System-pd41427376.html, 17/02/2020.

${ }^{36}$ „SRD-D1: The World's Smallest Object Detection Radar Sensor”, https://ainstein.ai/dronemakers-drone-service-providers/, 17/02/2020.

37 „SpotterRF C950 perimeter surveillance radar”, Anti Drone,

https://anti-drone.eu/products/perimeter-surveillance-radars/spotterrf-c950.html, 17/02/2020. 
Прегледни рад

\begin{tabular}{|l|l|l|}
\hline $\begin{array}{l}\text { Skylock's Drone } \\
\text { Detection Radar }\end{array}$ & $30 \mathrm{~kg}$ & $\begin{array}{c}\text { Detection Range (Objects) } \\
20 \mathrm{~km} \\
\text { Detection Range of small } \\
\text { drone } 0.3-3.5 \mathrm{~km}^{38}\end{array}$ \\
\hline
\end{tabular}

Drone jammers greatly increase the combat capabilities, safety and security of the units that use them. This section presents portable mobile jammers that can be operated by a single operator. Wireless communication, however, is vulnerable to a wide range of attacks. An attack that is particularly hard to detect in every wireless network is the radio jamming attack. ${ }^{39}$ The drone radio signal jammer blocks the connection between the hostile drone's video, telemetry, command, control and navigation systems, and the device's operator. The drone is effectively disabled and grounded by jamming the communication channels.

Table 5 - Drone jammers

\begin{tabular}{|c|c|c|c|c|}
\hline Equipment & Picture & Weigh & Distance & $\begin{array}{l}\text { Operating } \\
\text { time }\end{array}$ \\
\hline RF Patrol & & $710 \mathrm{~g}$ & $\begin{array}{c}\text { High RF } \\
\text { Environment } \\
\text { (Urban) - up to } \\
1 \mathrm{~km} \\
\text { Low RF } \\
\text { Environment } \\
\text { (Rural) - up to } 4 \mathrm{~km}\end{array}$ & $10 h^{40}$ \\
\hline Drone Node & & $17.2 \mathrm{~kg}$ & $1 \mathrm{~km}$ & $\begin{array}{c}\text { Activation } \\
\text { time: } 45 \text { min } \\
\text { (continuous) } \\
\text { Standby time: } \\
8+\text { hours }\end{array}$ \\
\hline
\end{tabular}

${ }^{38}$ „360 $0^{\circ}$ drone detection radar”, Skylock, https://www.skylock1.com/drone-detection/,17/02/2020.

${ }^{39}$ Dimitrios Kosmanos, Dimitrios Karagiannis, Antonios Argyriou, Spyros Lalis, and Leandros Maglaras, „RF Jamming Classification using Relative Speed Estimation in Vehicular Wireless Networks", Computer Science, 1/2019, pp. 1-10.

40 „Detect. Assess. Respond.”, Drone Shield, https://www.droneshield.com/, 01/02/2020.

${ }^{41}$ "Drone Node”, DroneShield, https://www.droneshield.com/dronenode, 01/02/2020. 


\begin{tabular}{|l|c|c|c|c|}
\hline $\begin{array}{l}\text { QR - MINI } \\
\text { Drone } \\
\text { Jammer } \\
\text { Shield }\end{array}$ & $2 \mathrm{~kg}$ & $1.5 \mathrm{~km}$ & $2 \mathrm{~h}^{42}$ \\
\hline $\begin{array}{l}\text { Skylock } \\
\text { Drone } \\
\text { Buster }\end{array}$ & \begin{tabular}{l}
$|c|$ \\
\hline
\end{tabular} & $2.26 \mathrm{~kg}$ & $0.75-1 \mathrm{~km}$ & $\begin{array}{c}3+\text { hrs. } \\
\text { continuous } \\
\text { jamming, } 10+ \\
\text { hrs. in RF } \\
\text { detection } \\
\text { mode }\end{array}$ \\
\hline
\end{tabular}

Navigation Tricking System launches fictitious satellite navigation signal, blocks the navigation signal in the air and falsifies the navigation system of drones, changes the recognition of the location of drones, and pursues drone to go away from the caution area, immediate land, or land at the pointed spot.

The drone operator locating system allows the location of the enemy drone operator to be determined with high accuracy and precision. The system is small in size, low in mass, convenient to carry and use, easy to operate and suitable for quick detection of remote control signals. Depending on the model, the maximum distance at which drone operator detection is possible also depends.

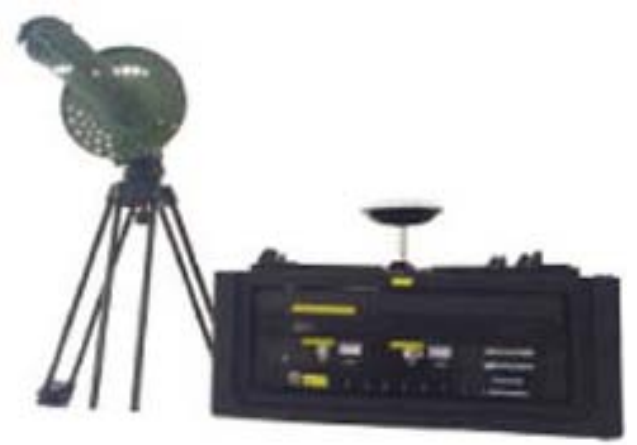

Figure 2 - The drone operator locating system

${ }^{42}$ Digital Eagle, „QR - MINI Drone Jammer Shield”, https://www.digitaleagle-uav.com/QR-MINIDrone-Jammer-Shield-pd6082290.html, 01/02/2020.

${ }^{43}$ "Skylock protecting your skies”, catalogue, Anti-drone systems, https://www.skylock1.com/drone-detection/, 17/02/2020. 
The objective of this part of the research is to determine if there is equipment that could be used by one person within infantry section and all studied Unmanned Aerial Vehicle (UAV) and Unmanned Ground Vehicle (UGV) systems have shown that they can be used by one person.

\section{Models and Variants of the Organisation in Rifle Section with a Drone Operator}

After studying the literature sources and interviewing experts, there have emerged several variants of the implementation of a drone and counter-drone operator duty in rifle section, as materials are gathered, analyzed and grouped into models. Those models are: Model 1 - a rifleman specialized to be an operator (Figure 3); Model 2 - a sniper specialized to be an operator (or completely converted sniper duty into drone operator duty) (Figure 4); and Model 3 - an assigned or embedded soldier (Figure 5).

The comparison between Models 1, 2 and 3 and their variants is not considered to be relevant because the researchers cannot conduct research in field conditions. These models and variants of the models are presented as the result of discovered models and variants of models.

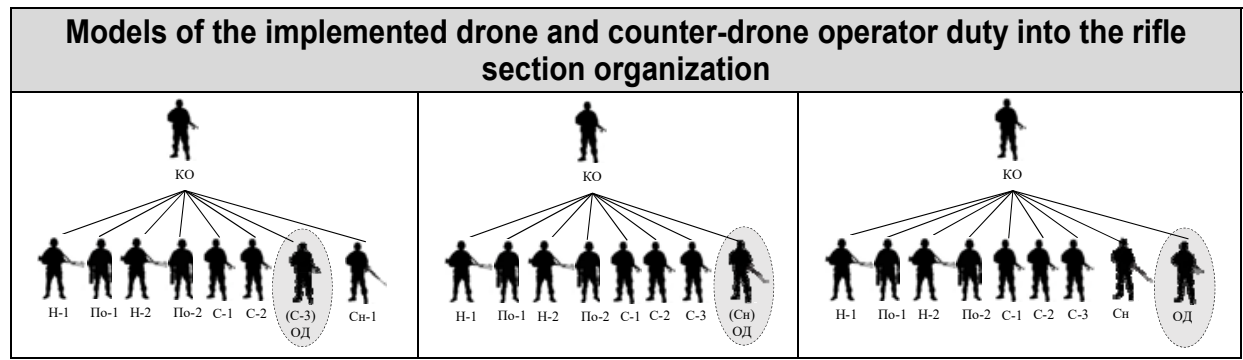

Figure $3-$ Model 1

Figure 4 - Model 2

Figure $5-$ Model 3

Each of these models represents a group of several variants, which are modeled following rules, where rifle section commander divides soldiers into two to three groups with the strength of three to four soldiers. ${ }^{44}$

The results of the previously conducted research "The Serbian Armed Forces infantry section subordination models" ${ }^{\prime \prime 5}$ are used as the basis for considering the position of a drone and counter-drone operator in the organizational structure of rifle section.

These variants of models are presented as follows.

${ }^{44}$ „Pravilo vojnik-odeljenje pešadije”, KzO GŠ VS, Vojna štamparija, Belgrade, 2016, points 16-19.

${ }^{45}$ Žnidaršič Vinko, Karavidić Zoran, „Analysis of regulated models of subordination in infantry section of Serbian Armed Forces", Vojno delo, Volume 71, Issue 4 (2019): DOI: 10.5937/vojdelo1904221Z, page 222. 


\section{Variants of Model 1: A drone operator as a specialized rifleman}

Model 1 implies that rifle section has the same number of nine soldiers and that one of riflemen gets additional training to be specialized as a drone and counter-drone operator (Figure 3).

Model 1, Variant 1.1 and 1.2 - These variants would consist of two, three-soldier fire-groups and a command element of three - a section leader, sniper, and drone operator (Figure 6 and Figure 7).

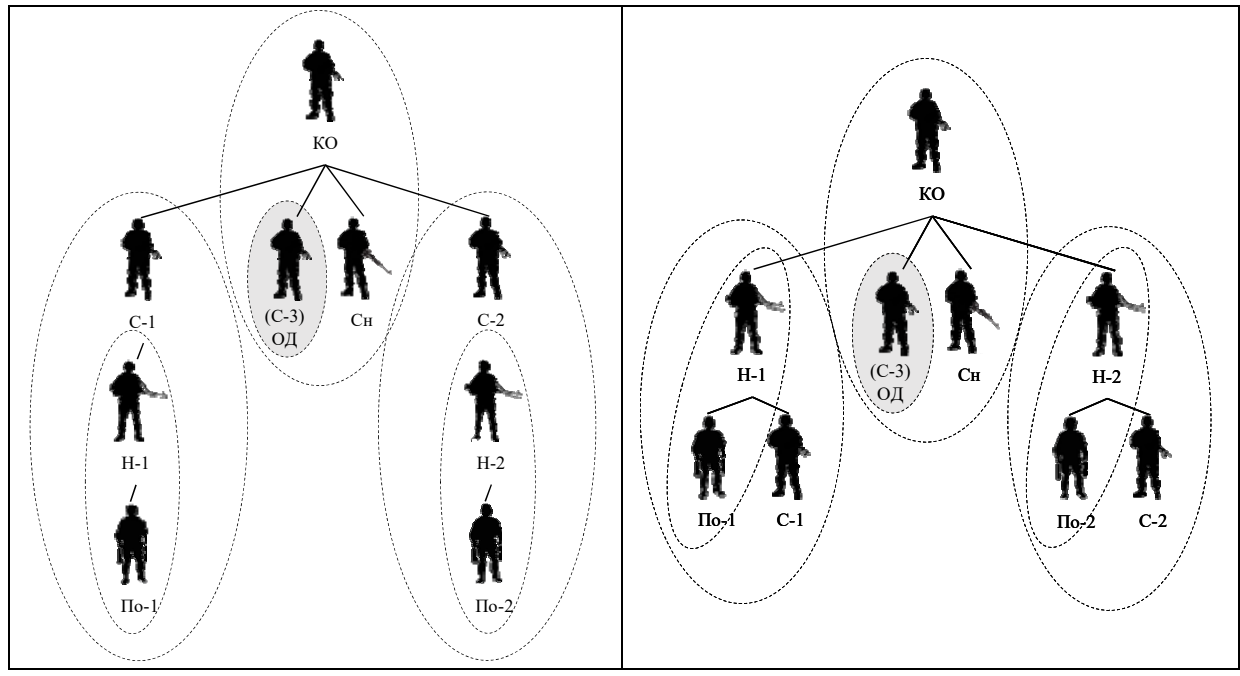

Figure 6 - Variant 1.1

Figure 7 - Variant 1.2

From the drone operator perspective of conducting his tasks, he will be in direct subordination to rifle section commander. He could individually perform a drone activity. For a counter-drone activity, he could collaborate with a sniper and he will definitely collaborate with other soldiers in rifle section, but this is not the subject of this pilot research.

The organization of the other two fire-teams does not have an influence on a drone and counter-drone operator position in the organization, but it would surely have an influence on performing this duty.

Model 1, Variant 1.3 - This variant would consist of two, three-soldier fire-groups and a command element of three. The group where a drone operator is consists of a group leader (machine gun operator), a machine gun assistant and a drone operator (Figure 8). In this variant of organization the machine gun crew (a machine gun operator and his assistant) and a drone operator will probably not be able to work in coordination at the time when the machine gun crew resolves fire tasks. Group commander is simply too overloaded with his duties to follow the command from rifle 
section commander, to be a machine gun operator and to command a machine gun assistant and a drone operator at the same time. Observation reports from a drone operator will probably not reach rifle section commander in time.

Model 1, Variant 1.4 - This variant would consist of two, three-soldier fire-groups and a command element of three. A fire-group where a drone operator is consists of a fire-group leader (drone operator) and the machine gun crew (a machine gun operator and his assistant) (Figure 9). This variant is probably not effective because fire-group commander is at the same time a drone operator and he is supposed to simultaneously perform drone tasks and command the machine gun crew. It is a complex and very demanding task for a drone operator, who is at the same time firegroup commander, to coordinate activities inside the fire-group (between his drone activities and the machine gun crew activities), with the first fire-group commander and rifle section commander.

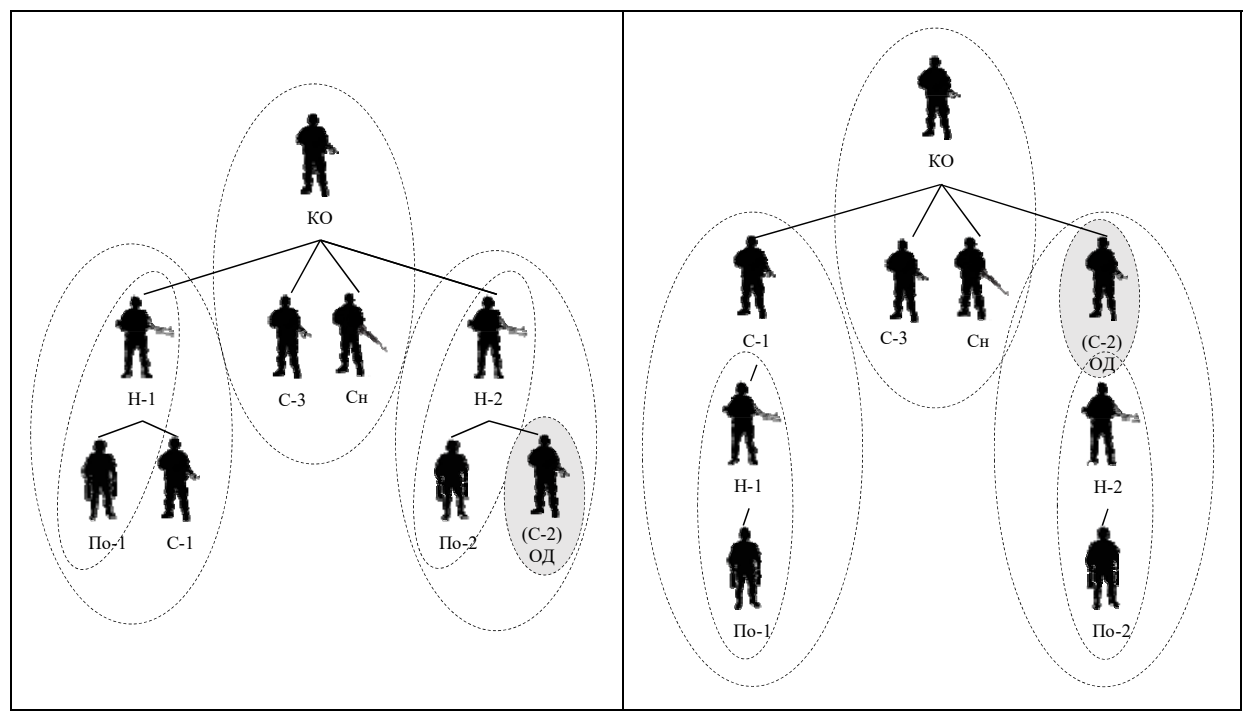

Figure 8 - Variant 1.3

Figure 9 - Variant 1.4

Model 1, Variant 1.5 - This variant would consist of rifle section commander and two, four-soldier fire-groups. A fire-group where a drone operator is consists of a firegroup leader (machine gun operator), the machine gun crew (a machine gun operator and his assistant), a drone operator and a sniper (Figure 10). A machine gun operator as fire-group commander coordinates the activities between the machine gun crew, a sniper and a drone operator inside this fire-group. He also has a demanding job to coordinate this group activities with the first fire-group commander and rifle section commander. 
If a drone operator has some observation, he would have to report it to fire-group commander (who is a machine gun operator), and a machinegun operator as firegroup commander will then report it to rifle section commander. This is a long and inefficient way of command, especially in combat situations when a machine gun operator is engaged with heavy fire.

Model 1, Variant 1.6 - This variant would consist of rifle section commander and two, four-soldier fire-groups. A fire-group where a drone operator is consists of a firegroup leader (rifleman), the machine gun crew (a machine gun operator and his assistant) and a drone operator (rifleman) (Figure 11).

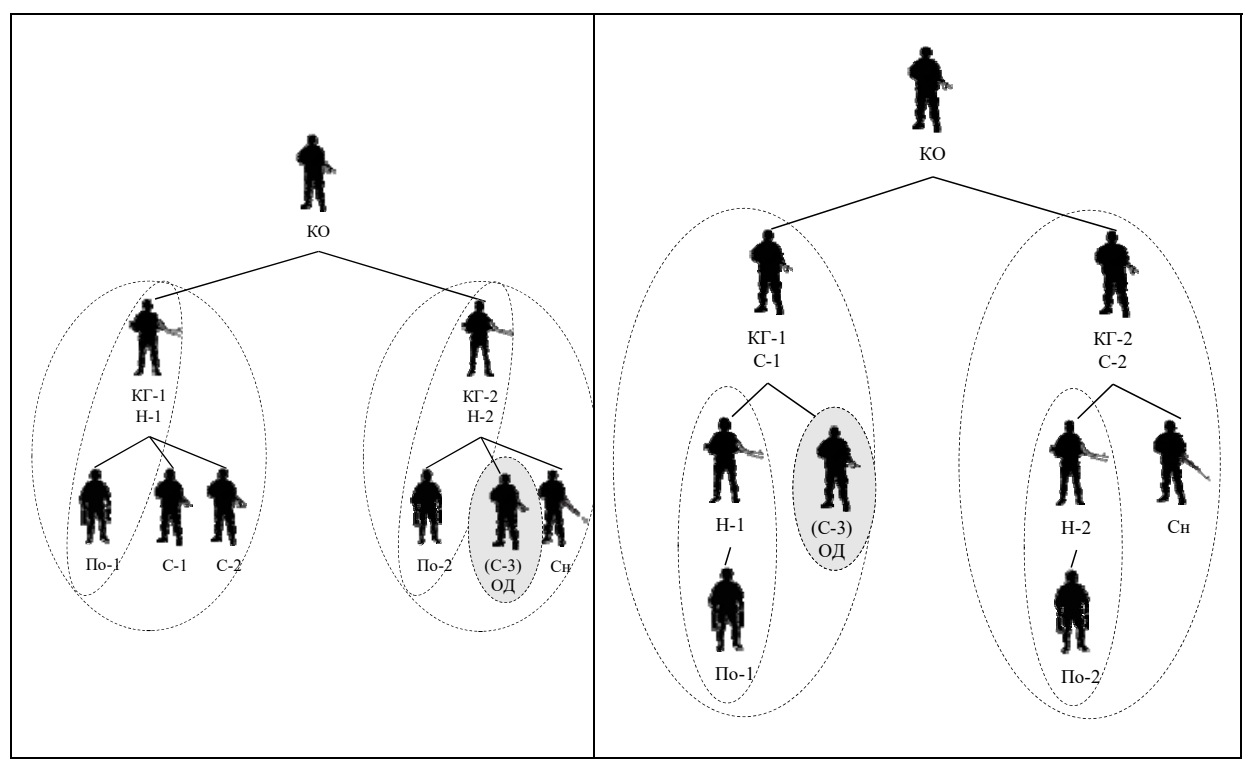

Figure 10 - Variant 1.5

Figure $11-$ Variant 1.6

This variant is considered to be effective because fire-group commander could command with one superior and two subordinate elements at the same time. The machine gun crew could resolve fire tasks and drone operators could resolve drone and counter-drone tasks, while fire-group commander could coordinate activities between these elements inside the fire-group. At the same time, he could coordinate with the second fire-group commander and the superior rifle section commander.

Model 1, Variant 1.7 - This variant would consist of rifle section commander and two, four-soldier fire-groups. A fire-group where a drone operator is consists of a fire-group leader (drone operator) and the machine gun crew (a machine gun operator and his assistant) and a sniper (Figure 12). 


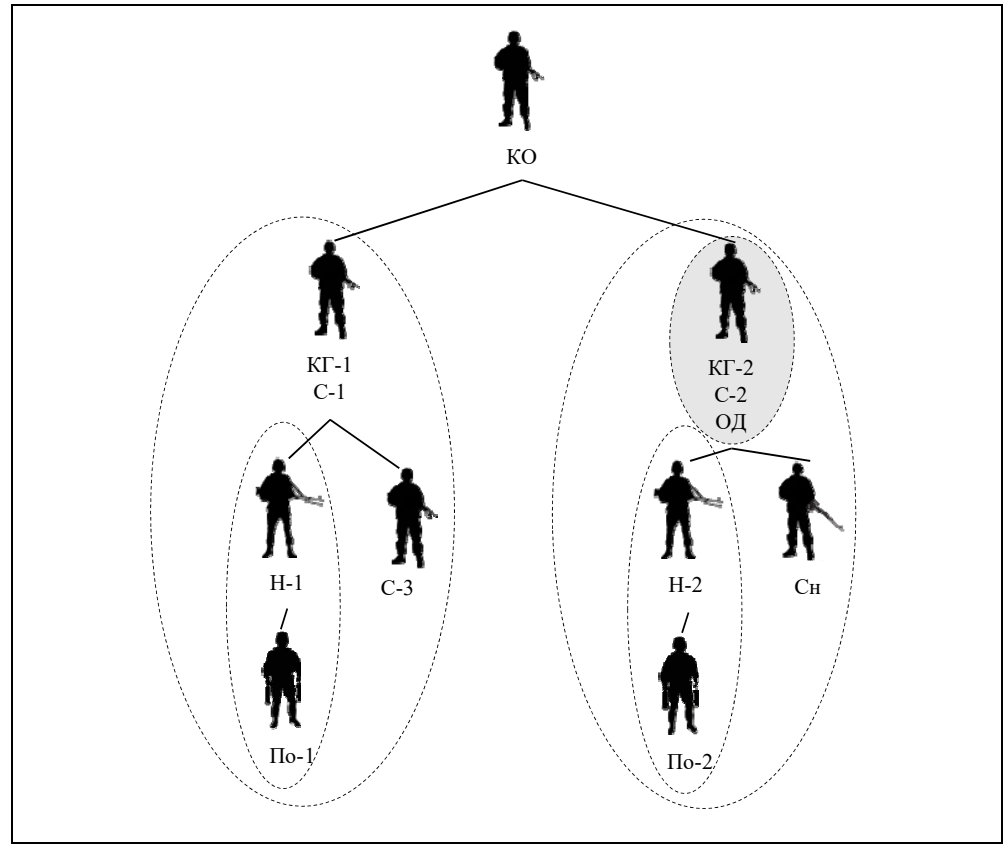

Figure 12 - Variant 1.7

This variant is probably not effective because fire-group commander is at the same time a drone operator and he is supposed to perform drone tasks and command tasks with the machine gun crew and a sniper at the same time. As firegroup commander a drone operator could not coordinate activities between him, the machine gun crew, a sniper, the first fire-group commander and rifle section commander.

\section{Variants of Model 2: A sniper as a drone and counter-drone operator}

Model 2 also implies that rifle section has nine soldiers. In this model, it is considered that a sniper could receive additional training or could replace a sniper gun with a rifle and be specialized as a drone and counter-drone operator (Figure 3). In this model this duty is marked as "a sniper-drone operator".

Model 2, Variant 2.1 and 2.2 - These variants would consist of two, three-soldier fire-groups and a command element of three - a section leader, a rifleman and a sniper-drone operator (Figure 13 and Figure 14).

The characteristics are similar as in Model 1, Variant 1.1 and 1.2. 


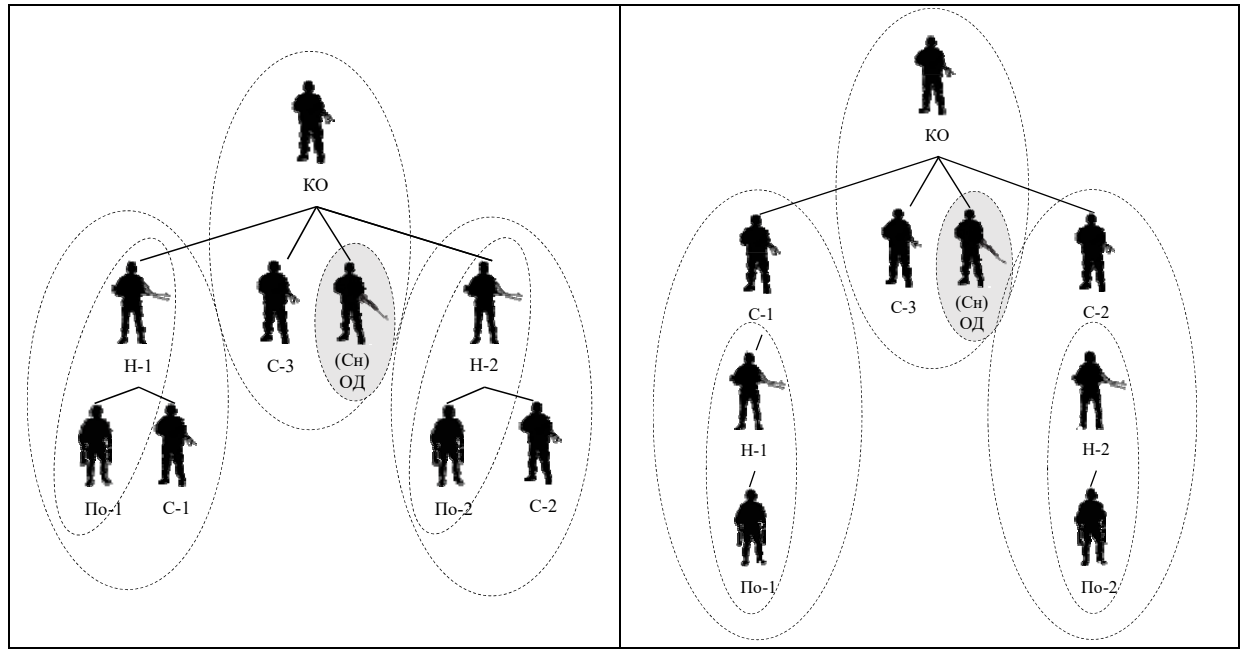

Figure 13 - Variant 2.1

Figure 14 - Variant 2.2

Model 2, Variant 2.3 - This variant would consist of rifle section commander and two, four-soldier fire-groups. A fire-group where a sniper-drone operator is consists of a fire-group leader (machine gun operator), an assistant to a machine gun operator, a rifleman and a sniper-drone operator (Figure 15).

Model 2, Variant 2.4 - This variant would consist of rifle section commander and two, four-soldier fire-groups. A fire-group where a sniper-drone operator is consists of a fire-group leader (rifleman), the machine gun crew (a machine gun operator and his assistant) and a sniper-drone operator (Figure 16).

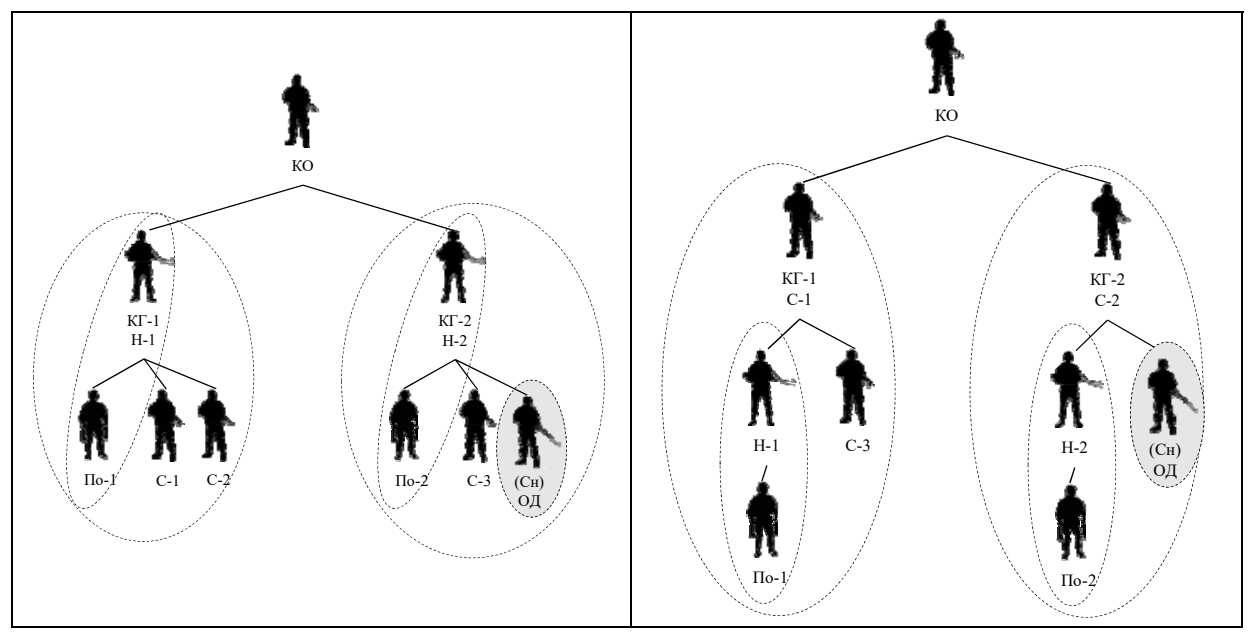

Figure 15 - Variant 2.3

Figure 16 - Variant 2.4 


\section{Model 3: A drone operator as an additional or "embedded" soldier}

Model 3 implies that rifle section has nine soldiers plus one. This specialized drone and counter-drone operator could be a part of the regular ten-man rifle section. He could also be an embedded or added soldier to nine-man rifle section (Figure 3).

Having an additional soldier in a section considerably changes the way how section works. That man with knowledge of how drones operate could also effectively perform a counter-drone activity with great confidence.

Model 3, Variant 3.1 and 3.2 - Having an additional soldier in a section considerably changes the way how section works. That man with knowledge of how drones operate could also effectively perform a counter-drone activity with great confidence (Figure 17 and Figure 18).

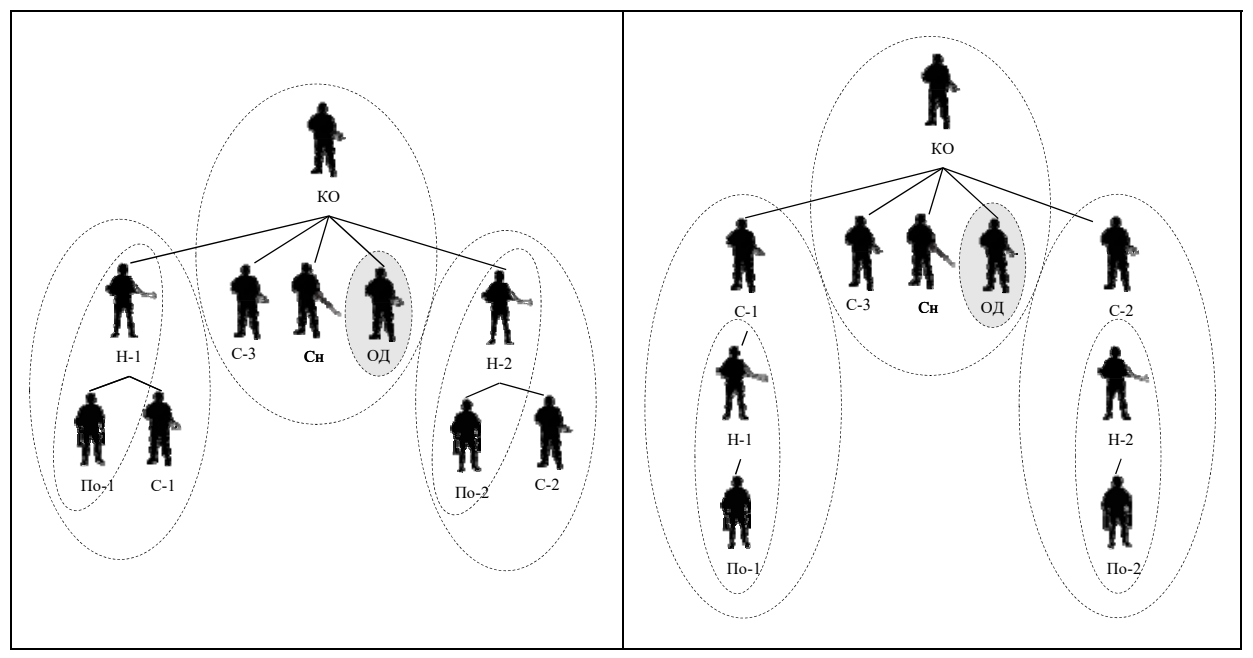

Figure 17 - Variant 3.1

Figure 18 - Variant 3.2

Model 3, Variant 3.3 - This variant would consist of two, three- and four-soldier fire-groups and a command element of three - a section leader, a rifleman and a sniper (Figure 19). A fire-group where a drone operator is consists of a fire-group leader (machine gun operator), an assistant to a machine gun operator, a rifleman and a drone operator.

Model 3, Variant 3.4 - This variant would have the same number of fire-groups and soldiers as in Variant 3.3, but with the different disposition of duties (Figure 20). A fire-group where a drone operator is consists of a fire-group leader (rifleman), the machine gun crew (a machine gun operator and his assistant) and a drone operator. 


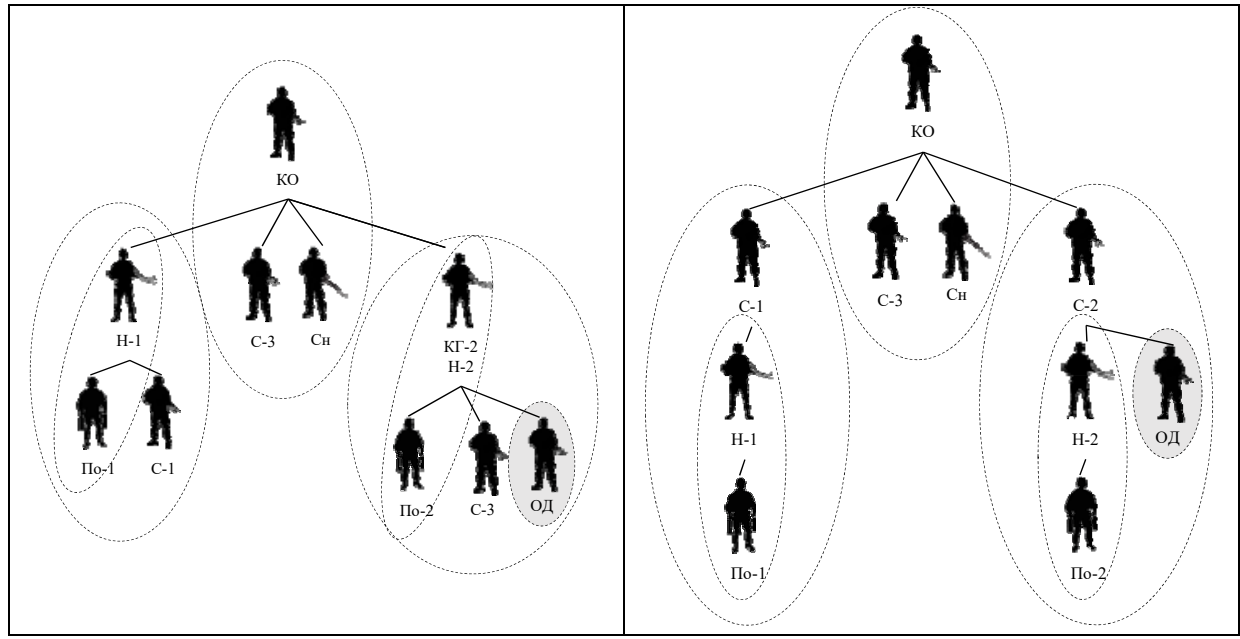

Figure 19 - Variant 3.3

Figure 20 - Variant 3.4

Model 3, Variant 3.5 - This variant would consist of rifle section commander and two fire-groups with four and five soldiers. A fire-group where a drone operator is consists of a fire-group leader (machine gun operator), an assistant to a machine gun operator, a rifleman, a sniper and a drone operator (Figure 21).

Model 3, Variant 3.6 - This variant would consist of rifle section commander and two fire-groups with four and five soldiers. A fire-group where a drone operator is consists of a fire-group leader (rifleman), the machine gun crew (a machine gun operator and his assistant), a sniper and a drone operator (Figure 22).

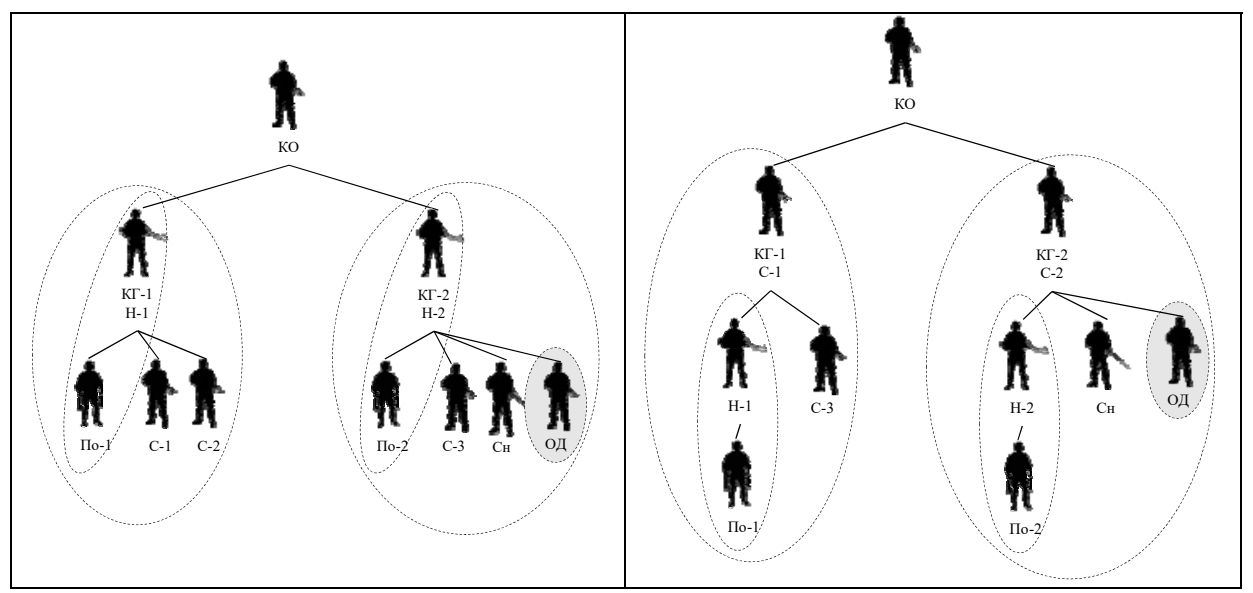

Figure 21 - Variant 3.5

Figure 22 - Variant 3.6 
Model 3, Variant 3.7 and Variant 3.8 - These variants would consist of two, foursoldier fire-groups and a command element of two - a section leader and a drone operator (Figure 23 and Figure 24).

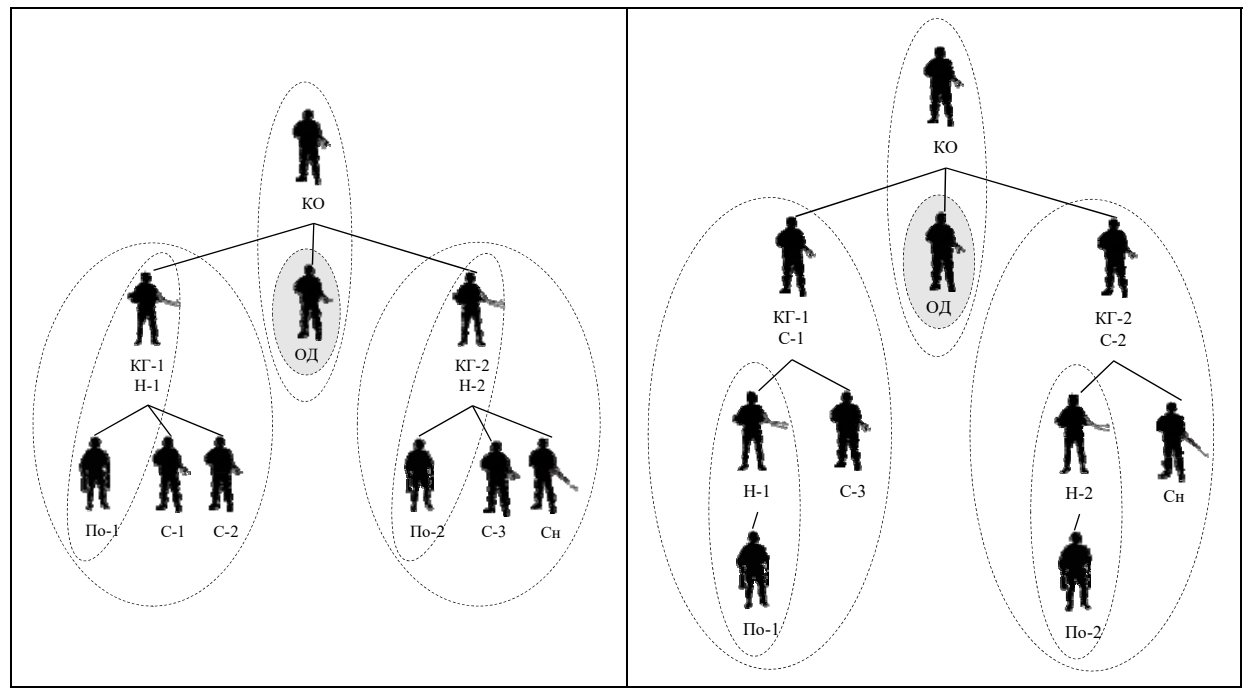

Figure 23 - Variant 3.7

Figure 24 - Variant 3.8

These two variants would have the same number of fire-groups and soldiers. A drone operator is directly subordinate to rifle section commander. Fire-groups would have the different disposition of duties.

\section{Conclusion}

This research has not been carried out with the aim to find one particular drone and counter-drone system for a drone operator. However, it has been confirmed that there are systems that can be operated by one person and all systems which have been presented are considered eligible for the use in rifle section.

The research objective of finding a set of models and variants of models is fulfilled. In the first and second model, no changes in the number of soldiers inside rifle section have been considered. Specializing one rifleman or sniper to be a drone and counter-drone operator will not change the number of soldiers, but it will change the organizational structure inside rifle section.

The third model, where a drone and counter-drone operator is an embedded soldier has an influence on the organizational structure, command and other logistical 
things. One person in all rifle sections increases the number of persons in major tactical military formations, but it could be done if the extent of the threat indicates the need to deploy one of modeled organizational variants with a drone operator.

Using drones instead of human soldiers for reconnaissance and other activities increases safety and it could be done with the implementation of at least one variant of the three selected models.

This research uses a theoretical study of possible variants of drone operator positions inside the organization of rifle section with the aim to prepare materials for practical survey in the field. Only by research in the field conducted by soldiers and drones on friendly and enemy sides it would be possible to determine which model and variant are the best for operational use.

In this research, the aim is not to find the best drone and counter-drone system for an operator in rifle section. The aim is to find and describe every possible model and variant of models for the obvious and necessary phase of the field tests in real or near-real conditions.

\section{Literature}

[1] Aleksandar Milić, Aca Ranđelović, Marko Radovanović, „Use of drones in operations in the urban environment", $5^{\text {th }}$ International Scientific conference Safety and crisis management - Theory and practise Safety for the future - SecMan Regional Association for Security and Crisis Management S4 GLOSEC Gobal security doo.., Belgrade, 2019, pp. 124-130.

[2] Anjali Nawalagatti and Arun S. Tigadi, „Anti-Drone System With Multiple Surveillance Technologies", International Journal of Engineering Science Invention, Vol. 8, May 2019, pp. 36-41.

[3] „Anti-Drone System”, Hanvy, https://www.antidrone.cn/anti-drone-system/hand-heldanti-drone-gun.html, 01/02/2020.

[4] Arthur Holland Michel, Counter - drone system $2^{\text {nd }}$ edition, Center for the Study of the Drone at Bard College, New York, 2019, pp. 5-12.

[5] Barry Jenkins, „We should fear the use of killer drones like in Venezuela”, The Independent, 11 August 2018, https://www.independent.co.uk/voices/killer-dronesvenezuela-president-attack-uk-aircraft-warfare-isis-syria-a8487536.html,15/11/2019.

[6] „Black Hornet Nano”, https://upload.wikimedia.org/wikipedia/commons/thumb/e/ed/Black_Hornet_Nano_Helico pter_UAV.jpg/800px-Black_Hornet_Nano_Helicopter_UAV.jpg, 23/09/2020.

[7] „Bayraktar Mini Unmanned Aerial Vehicle”, https://www.armytechnology.com/projects/bayraktar-uav/bayraktar-uav1, 23/09/2020.

[8] Christopher F Foss, „Serbia advances Milos UGV development”, Jane's, 5 July 2019, https://www.janes.com/article/89709/serbia-advances-milos-ugv-development, 01/02/2020.

[9] „Daljinski upravljana besposadna zemaljska platforma Miloš”, PPT Namenska, http://www.ppt-namenska.rs/milos.html, 10/02/2020. 
[10] „Detect. Assess. Respond.”, Drone Shield, https://www.droneshield.com/, 01/02/2020.

[11] Digital Eagle, „QR - MINI Drone Jammer Shield”, https://www.digitaleagle-uav.com/QR-MINI-Drone-Jammer-Shield-pd6082290.html, 01/02/2020.

[12] Dimitrios Kosmanos, Dimitrios Karagiannis, Antonios Argyriou, Spyros Lalis, and Leandros Maglaras, „RF Jamming Classification using Relative Speed Estimation in Vehicular Wireless Networks", Computer Science, 1/2019, pp. 1-10.

[13] Dragan Stevanović, Olga Isaijeva, Dejan Ranđelović, Miroslav Terzić, „Upotreba dronova u vojne svrhe", 14. Međunarodno savetovanje Rizik i bezbednosni inženjering zbornik radova, Visoka tehnička škola strukovnih studija, Novi Sad, 2019, pp. 132-144.

[14] „DroneNode”, DroneShield, https://www.droneshield.com/dronenode, 01/02/2020.

[15] „Drone Products Lineup”, Ainstein, https://ainstein.ai/downloads/Datasheets/AINSTEIN_DRONEDATA.pdf, 17/02/2020.

[16] Eleftheria Mitka, Spiridon G. Mouroutsos, „Classification of Drones”, American Journal of Engineering Research, Vol 6, 7/2017, pp. 36-41.

[17] „EMT Aladin”, https://alchetron.com/EMT-Aladin\#emt-aladin-62593bd3-198f-471da78b-dc741a5ff47-resize-750.jpeg, 23/09/2020.

[18] John Grady, „Panel: Services Should Better Leverage Each Other's Tech Development", Joint Operations, USNI News, 17 March 2017, https://news.usni.org/2017/03/17/panel-services-better-leverage-others-techdevelopment-joint-operations, 01/02/2020.

[19] Jović Željko, „Strategijski i legalni aspekti borbene upotrebe dronova u protiv terorističkim operacijama SAD", Vojno delo, volume 69, issue 7 (2017):

DOI: 10.5937/vojdelo1707468J.

[20] „Kalashnikov creates new anti-drone gun”, Army Recognition, 10 July 2019, https://www.armyrecognition.com/weapons_defence_industry_military_technology_uk/ka lashnikov_creates_new_anti-drone_gun.html, 01/02/2020.

[21] Lewis James, „Contemporary Operating Environment - The Battle Of Marawi: Small Team Lessons Learned For The Close Fight”, The Cove, 26 November 2018, https://cove.army.gov.au/article/the-battle-marawi-small-team-lessons-learned-the-closefight, 30/01/2020.

[22] „Lockheed Martin”, https://www.flickr.com/photos/lockheedmartin/5084393936/lightbox/, 23/09/2020.

[23] Mahmood Ali, Aldroubi Mina, „Houthi rebel drone targets senior officers at Yemen's Al Anad military base", thenational, 10 January 2019,

https://www.thenational.ae/world/mena/houthi-rebel-drone-targets-senior-officers-atyemen-s-al-anad-military-base-1.811544, 03/08/2019.

[24] „MTGR is a Lightweight Combat Proven Tactical Robot”, Roboteam, http://robo-team.com/products/mtgr/\#s-6, 05/02/2020.

[25] Nikolai Novichkov, Dmitry Fediushko, „Russia enters C-UAV domain”, European Defence Review, 26 November 2019, https://www.edrmagazine.eu/russia-enters-c-uav-domain, 01/02/2020. 
[26] „Pravilo vojnik-odeljenje pešadije”, KzO GŠ VS, Vojna štamparija, Belgrade, 2016.

[27] „QR-12 Drone Detection And Jamming System”, Digital Eagle,

https://www.digitaleagle-uav.com/QR-12-Drone-Detection-And-Jamming-Systempd41427376.html, 17/02/2020.

[28] „Radar Drone Detection Introduction”, Hanvy, https://www.antidrone.cn/anti-dronesystem/radar-drone-detection.html, 17/02/2020.

[29] „Rambow”, Army Guide, http://www.army-guide.com/eng/product.php?prodID=5923\&printmode=1, 05/02/2020.

[30] Reid David, „A swarm of armed drones attacked a Russian military base in Syria", SNBC, 11 january 2018, https://www.cnbc.com/2018/01/11/swarm-of-armed-diydrones-attacks-russian-military-base-in-syria.html, 30/01/2020.

[31] Reid David, „Saudi Aramco reveals attack damage at oil production plants”, SNBC, 21 September 2019, https://www.cnbc.com/2019/09/20/oil-drone-attack-damagerevealed-at-saudi-aramco-facility.html, 14/02/2020.

[32] Roni Sontani, „Pishchal-PRO, Senapan Elektrik untuk Melumpuhkan Drone Berukuran Mini", Airspace Review, 4 December 2019, https://www.airspace-review.com/2019/12/04/pishchal-pro-senapan-elektrik-untukmelumpuhkan-drone-berukuran-mini/, 17/02/2020.

[33] „Russians Have Made a Flying Rifle”, English Russia, 28 March 2019, https://englishrussia.com/2019/03/28/russians-have-made-a-flying-rifle/, 01/02/2020.

[34] „Russian UAVs. Part 1”, http://igorrgroup.blogspot.com/2010/05/russia-uavs-part1.html, 23/09/2020.

[35] „RQ-11 Raven US Army Unmanned Aerial Vehicle”, http://usaircraftpics.blogspot.com/2012/03/rq-11-raven-us-army-unmanned-aerial.html, 23/09/2020.

[36] „Skylock protecting your skies”, cataloge, Anti-drone systems, https://www.skylock1.com/drone-detection/, 17/02/2020.

[37] „SpotterRF C950 perimeter surveillance radar”, Anti Drone, https://anti-drone.eu/products/perimeter-surveillance-radars/spotterrf-c950.html, 17/02/2020.

[38] Xiufang Shi, Chaoqun Yang, Weige Xie, Chao Liang, Zhiguo Shi, Jiming Chen, „Anti-Drone System with Multiple Surveillance Technologies: Architecture, Implementation, and Challenges", IEEE Communications Magazine, Vol. 56, 4/2018, pp. 68-74.

[39] Žnidaršič Vinko, Karavidić Zoran, „Analysis of regulated models of subordination in infantry section of Serbian Armed Forces", Vojno delo, volume 71, issue 4 (2019): DOI: $10.5937 /$ vojdelo1904221Z.

[40] „360 drone detection radar”, Skylock, https://www.skylock1.com/drone-detection/,17/02/2020. 


\section{Моделовање организационе имплементације оператера за дронове и противдронска дејства у стрељачко одељење Војске Србије}

Д

ронови су једна од нових претњи тактичким јединицама. Оружане снаге их користе са промењивим успехом у операцијама, али најнижа тактичка јединица, као што је стрељачко одељење, није још увијек спремна да изводи операције у којима би употребило дронове и противдронске мере. Дронови имају широк спектар могућности и користе се како за цивилне тако и за војне сврхе. Упоредо са развојем дронова, развијају се и средства за противдронска дејства.

У првом делу резултата истраживања представљено је неколико малих беспилотних летелица и противдронских система којима може руковати један човек како би се показало да постоји више од једног система који се може изабрати за оперативну употребу. То такође показује да је један војник у стрељачком одељењу способан да рукује са дронским и противдронским системима.

Циљ овог рада је да се истражи организациона структура и утврде организационе могућности да се дужност оператера за дронове и противдронска дејства имплементира у стрељачко одељење. У ту сврху истраживачки тим је обавио низ интервјуа са официрима и подофицирима Војске Србије и Министарства одбране и ова дужност је у раду дефинисана као „дрон оператор“ на примеру стрељачког одељења Војске Србије где је моделована да може бити дужност 1) специјализованог стрелца, 2) дообученог снајперисте или 3) додатог војника.

Кључне речи: стрељачко одељење, дрон, противдронско дејство, дрон-оператор, командовање, мала тактичка јединица 